Annals of Warsaw University of Life Sciences - SGGW

Land Reclamation No 49 (3), 2017: 179-199

(Ann. Warsaw Univ. of Life Sci. - SGGW, Land Reclam. 49 (3), 2017)

\title{
Effects of cypress knee roughness on flow resistance and discharge estimates of the Turkey Creek watershed
}

\author{
DOROTA MIROSLAW-SWIATEK ${ }^{1}$, DEVENDRA M. AMATYA ${ }^{2}$ \\ ${ }^{1}$ Faculty of Civil and Environmental Engineering, Warsaw University of Life Science - SGGW \\ ${ }^{2}$ Center for Forested Wetlands Research, US Forest Service, Cordesville
}

\begin{abstract}
Effects of cypress knee roughness on flow resistance and discharge estimates of the Turkey Creek watershed. In this study effects of cypress knees as vegetation resistance factor on Turkey Creek watershed discharge calculation were analyzed. The Turkey Creek watershed is a $3^{\text {rd }}$ order stream system draining an approximate area of 5,240 ha. It is located at $33^{\circ} 08^{\prime} \mathrm{N}$ latitude and $79^{\circ} 47^{\prime} \mathrm{W}$ longitude, approximately $60 \mathrm{~km}$ north-west of City of Charleston in South Carolina (USA). Turkey Creek (WS 78) is typical of other watersheds in the south Atlantic coastal plain. In the case of Turkey Creek watershed, one of the main channels and riparian floodplain vegetation contains cypress trees. Cypress trees live in moist or swampy regions along the Atlantic coastal plain. The cypress trees are characterized by the unique root system called knees that appear just above the water line, up to $1.2 \mathrm{~m}$ above water surface. This study is conducted to examine the effects of roughness of cypress knee as related to its shape (diameter and height) on discharge estimates of the Turkey Creek watershed. Hydraulic characteristics of the cypress knees were determined by field inventory in selected cross-section along the main stream channel. The Pasche method was used to calculate the total Darcy-Weisbach friction factor in discharge capacity calculation of the study watershed. The results of this study show that the effect of vegetation shape in the Pasche approach is significant. If the variability of vegetation stem diameter is taken into consideration in the calculations, an increase by $10-32 \%$ in the values of friction coefficients occurs.
\end{abstract}

Key words: South Carolina, Francis Marion National Forest, discharge calculation, riparian floodplain, roughness coefficient, hydraulic resistance, Pasche method

\section{INTRODUCTION}

Riparian floodplains are among the most biologically diverse and productive ecosystems worldwide, but their ecological integrity is compromised by regulation of flow by dams, reservoirs, and revetments (Tockner and Standford 2002) as cited in Whited et al. (2007). The diversity of aquatic and terrestrial floodplain habitats is controlled and maintained by variations within the hydrologic regime that influence habitat distribution and turnover. A primary goal in riparian ecology is to develop general frameworks for prediction of vegetation response to changing environmental conditions including flow standards for rivers and streams (Merritt et al. 2009). At the same time, the vegetation species type, structure, and distribution on the channel and riparian floodplain also influence velocity of flow due to vegetation resistance or, for that matter, discharge magnitudes, especially for high flow events when the stage of the water is on floodplain exceeding the bank-full capacity. Riparian vegetation type, composition, structure, and its abundance on floodplains exert a strong influence on riparian surface and subsurface hydrology, discharges of rivers and streams, and significantly affect flood extent in the valley, which is a part 
of self-regulatory mechanism in river-floodplain ecosystem relations (Rood et al. 2005, Benjankar et al. 2009). Similarly, it has been well documented that riparian vegetation can prevent or reduce contaminant transport to surface waters via runoff (Sheridan et al. 1999). The conditions of flood water discharge in valley are shaped by the existing vegetation cover. Many studies were carried out in the past to investigate the hydraulic impact of natural roughness such as bank and floodplain vegetation or bed roughness of different textures on the overall flow field (Pasche and Rouve, 1985, Helmio 2002, Wu 2008, Miroslaw-Swiatek 2012).

However, discharge rates and time of travel of surface runoff contributing to the stream discharge at various locations along the main stream as well as tributaries of streams that are often influenced by resistance of vegetation type/density both on the banks and riparian buffers are rarely available although they are often needed to evaluate the culvert and bridge discharge capacities, flooding and pollutant loadings from subwatersheds draining lands with various management practices. Such measurements or estimates are even more important for validating distributed watershed-scale models for their internal consistency as they are generally validated with measurement at the main watershed outlet only (Santhi et al. 2008, Amatya and Jha 2011). Furthermore, these estimates are becoming increasingly important in evaluating the influence of riparian vegetation ecosystem on flow regime characterized by stage, velocity, and discharge at various locations of the rivers and streams, especially those affected by urbanization (White and Greer 2006).

Therefore, there is a great need for an improved estimation of velocity and discharge method in which flow resistance caused by the vegetative elements takes into consideration the influence of their size, shape, flexibility and concentration on the extent of their submergence (Wilson and Horrit 2002). This approach withdraws from a typical methodology, where flow resistance is assigned to a channel and its floodplain surface occupied by vegetation based on tables of Manning's $n$ given by Chow (1959). Generally flow resistance models for rigid vegetation such as trees or bushes which have used the most simplistic approach where plants are described as rigid vertical cylinders (Pasche and Rouve 1985, Nepf 1999). The main question of this paper is the effect of rigid vegetation shape in the Pasche approach in the friction factor calculation.

In the case of the Turkey Creek watershed, one type of the riparian floodplain vegetation is cypress (Taxodium), which can be considered a rigid plant. There has been only a limited study on effects of cypress knees as a vegetation resistance factor on discharge measurements of streams and rivers (Miroslaw-Swiatek and Amatya 2011). The majority of publications describe biological functions of Cypress knee in swampy regions (Brown 1984, Bonness 2011). Therefore, the main objective of this study is to examine the effects of cypress knee roughness as related to its shape (diameter and height) on discharge estimates of Turkey Creek watershed on a coastal forested landscape in South Carolina (USA). 


\section{MATERIAL AND METHODS}

\section{Determination of friction factors}

The flow resistance for the riverbed covered by cypress knee was calculated according to the method by Pasche and Rouve (1985), where a momentum sink term is expressed in terms of a drag coefficient. The Darcy-Weisbach flow formula with the friction factor $(\lambda)$ was used in the channel discharge calculation.

In this article high vegetation (trees and shrubs) is understood as higher than water flow depth and in small degree affected by hydrodynamic water pressure; medium vegetation as approximately equal to water depth (mostly shrubs) and low vegetation refers mostly to sedge and grass communities. The assumed criteria are somewhat arbitrary and, in fact, the same vegetation can be ranked into different types in terms of the variability of the natural water levels. The main basis for hydraulic calculations of the river flow, where the structure of high vegetation is taken into account, is that water flow resistances are the same as vegetation resistances, which occur when water overflows regularly distributed vegetation with averaged geometric parameters. The parameters which describe the vegetation of the floodplain and are used in calculations are the average diameter of tree or shrub branches $\left(d_{p}\right)$ and distances between them in the direction of the water flow $\left(a_{x}\right)$ and perpendicular to it $\left(a_{y}\right)$. The mentioned parameters of the cypress trees were determined on the basis of field measurements at specified cross-section in the area of the water flow.
The resistance of flow caused by the bed roughness is calculated from the formula given by Colebrook and White (Pasche and Rouve 1985):

$$
\frac{1}{\sqrt{\lambda_{s}}}=2.03 \log \left(\frac{2.51}{\operatorname{Re} \sqrt{\lambda_{\mathrm{s}}}}+\frac{k_{s}}{14.84 R}\right)
$$

where:

$\lambda_{s}-$ friction factor of low vegetation or a part of the cross-section, which is devoid of vegetation (-);

$\mathrm{Re}$ - the Reynolds number;

$k_{s}$ - roughness height of the low vegetation or a part of the cross-section, which is devoid of vegetation (m).

As it results from the Colebrook-White law, the friction factors of flow depend on the Reynolds number and on the relative roughness $\left(k_{s} / R\right)$. The influence of the Reynolds number on friction factors decreases as its value and relative roughness of the channel sides both increases. In natural channels the influence of the Reynolds number for values higher than 25,000 may be neglected without any harm to the precision of calculations. Therefore, application of the Equation (1) for practical calculations is recommended, in the following form:

$\frac{1}{\sqrt{\lambda_{s}}}=-2.03 \log \left(\frac{k_{s}}{14.84 R}\right)$

The friction factor $\lambda_{p}$ for trees and bushes (the submerged part of high vegetation) is calculated from the following expression (Pasche and Rouve 1985):

$\lambda_{p}=\frac{4 h_{z} d_{p}}{a_{x} a_{y}} C_{W R}$ 
where:

$h_{z}$ - height of submerged part of trees (m);

$d_{p}$ - trees diameter $(\mathrm{m})$;

$a_{x}, a_{y}$ - distance between plants along and perpendicularly to the flow, respectively (m);

$C_{W R}$ - dimensionless drag coefficient for the submerged part of trees or bushes.

The drag coefficient $\left(C_{W R}\right)$ depends on the ratio of the flow velocity $\left(V_{i}\right)$ to the average velocity $\left(V_{v}\right)$ of the flow going through tree-overgrown areas (relative velocity $-V_{r}$ ), and is described by the following empirical formula (Pasche and Rouve 1985):

$$
C_{W R}=\left(1.1+2.3 \frac{d_{p}}{a_{y}}\right)\left(V_{r}\right)^{2}+2\left(\frac{1}{1-d_{p} / a_{y}}-1\right)
$$

$$
V_{r}^{2}=\left(\frac{V_{i}}{V_{v}}\right)^{2}=0.6+0.5 \log \left(\frac{a_{x}}{a_{y}}\right)
$$

The expression (5) is valid when 0.05 $<d_{p} / a_{y}<3$ and $0.2<a_{x} / a_{y}<2$.

The resistance of flow in parts of cross-sections overgrown by high vegetation depends on both the vegetation and the bed roughness. The friction factor for this area is the following sum:

$\lambda=\lambda_{s}+\lambda_{p}$

where:

$\lambda$ - average friction factor (-);

$\lambda_{s}-$ friction factor caused by channel bed roughness or low vegetation (-); $\lambda_{p}-$ friction factor for the non-submerged and non-flexible vegetation (high vegetation) (-).
Mean velocity $(v)$ in a channel is calculated from the Darcy-Weisbach equation, which results from the momentum balance in the cross-section:

$v=\sqrt{\frac{8 \mathrm{gR} S_{f}}{\lambda}}$

where:

$v$-average velocity in the main channel $(\mathrm{m} / \mathrm{s})$

$\mathrm{g}$ - acceleration of gravity $\left(\mathrm{m} / \mathrm{s}^{2}\right)$

$S_{f}$ - hydraulic slope (-);

$\lambda$ - total friction factor (-).

The total friction factor $(\lambda)$ in Equation (7) is described by Equation (6).

The hydraulic characteristics $d_{p}, a_{x}$, $a_{y}$ are determined based on field measurements in the area of the water flow. Floodplains and riparian zones of rivers and streams are usually covered by groups of trees or bushes. The inventory sampling of those trees or bush groups is generally carried out on elementary, rectangular-like areas $A_{\text {pro }}$, which are 10 by $20 \mathrm{~m}$ in size. The surface of the elementary, inventory area should not exceed several square meters (DVWK - Merkblätter 1991). On the basis of the performed inventory of trees and bush groups, the substitute diameter of trees or bush branches is calculated and mean distances between plants are estimated. The substitute diameter is the mean value of the diameters measured at the water level elevation:

$d_{p}=\frac{\sum d_{i}}{n}$

where:

$d_{p}$ - substitute diameter of trees/bushes; $d_{i}$ - diameter of a tree/bush; 
$n$ - number of trees or bush branches in the inventory area.

The substitute distance between the trees or branches in the direction of water flow $\left(a_{x}\right)$ and perpendicular to it $\left(a_{y}\right)$, when these distances are equal $\left(a_{x}=a_{y}\right)$, is calculated from the following formula:

$a_{x}=a_{y}=\sqrt{\frac{A_{\text {pro }}}{n}}$

When these distances are not equal, based on the measurement results, the surface occupied by one plant is calculated by means of the following equation: $a_{x} \cdot a_{y}=A_{\text {pro }} / n$, next, the mean value of the distance ratio is calculated: $a_{y} / a_{x}=C$, and by means of a substitution: $a_{y}=C \cdot a_{x}$, the distance $a_{x}=\left[A_{\text {pro }} /(n \cdot C)\right]^{0.5}$ is achieved.

\section{STUDY AREA}

Turkey Creek watershed is the third-order stream system draining an approximate area of 5,240 ha based on the recently obtained LiDAR-based DEM (Fig. 1). It is located at $33^{\circ} 08^{\prime} \mathrm{N}$ latitude and $79^{\circ} 47^{\prime} \mathrm{W}$ longitude, approximately $60 \mathrm{~km}$ north-west of City of Charleston, near Huger, in Berkeley County of South Carolina (Fig. 1). It is the headwaters of East Cooper River, a major tributary of Cooper River, which drains to Charleston Harbor. Turkey Creek (WS 78) is typical of other watersheds in south Atlantic coastal plain, where rapid urban development is taking place (Amatya and Jha 2011). The topographic elevation of the watershed varies from $2 \mathrm{~m}$ at the outlet to $14 \mathrm{~m}$ above mean sea level (AMSL). The sub-tropical climate is characteristic of the coastal plain having

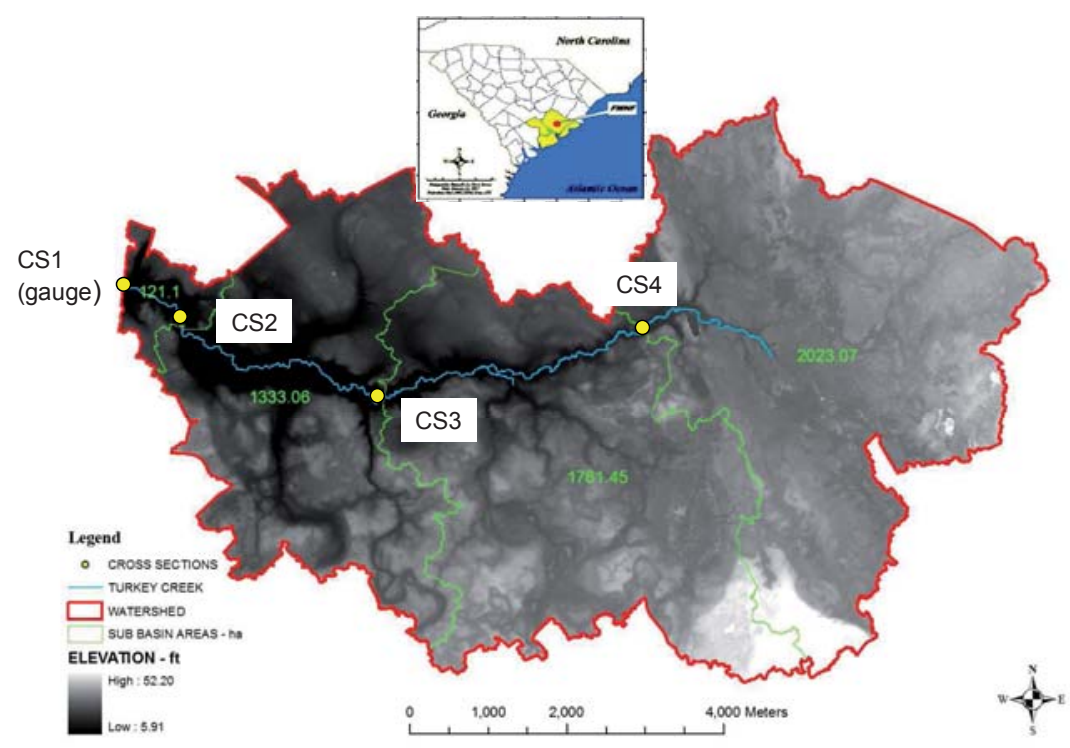

FIGURE 1. Location of the Turkey Creek watershed on Francis Marion National Forest in South Carolina lower coastal plain. Also shown are the locations of the cross-sections (CS) including the gauging station at CS1 
hot and humid summers and moderate winters. Accordingly, the minimum and maximum air temperatures, based on a 50-year (1951-2000) record at the Santee Experimental Forest, were recorded as $-8.5^{\circ} \mathrm{C}$ and $37.7^{\circ} \mathrm{C}$, respectively, with an average daily temperature of $18.4^{\circ} \mathrm{C}$. Annual rainfall at the site varied from 830 to $1,940 \mathrm{~mm}$, with an average of 1,370 $\mathrm{mm}$ based on the 50-year (1951-2000) data. Seasonally, the winter is generally wet with low intensity long duration rain events and the summer is characterized by short duration, high intensity storm events; tropical depression storms are not uncommon. The main channel has braided in some locations, which is anastomosed and stable with mature root systems of bottomland species such as bald cypress and tupelo gum along the streambanks and in some locations in the channel. Sand is the dominate substrate material. Details of the study site can be found elsewhere (Amatya and Jha 2011).

Hydrography of the Turkey Creek watershed is characterized by a $9.75 \mathrm{~km}$ long main channel and its network of narrow tributaries with wide floodplains. The right bank, or north bank, of Turkey
Creek has shorter and fewer tributaries compared to the left bank. Many of the tributaries are ephemeral and intermittent, including certain upper reaches of the main creek. Most channels within Turkey Creek watershed are larger in width compared to depth. The main channel is $10 \mathrm{~m}$ or even more towards downstream, often with wide flood plains and islands in the winding parts of the creek (Haley 2007) - Figure 2.

Turkey Creek watershed is located in the Francis Marion National Forest, which is comprised primarily of pine, oak, and cypress trees on the coastal plain of South Carolina. Today this national forest remains a lush landscape of pine stands and wildlife-filled swamps and marshes shaded by towering bald cypress trees. Over $50 \%$ of the forest is comprised of Bald Cypress, Water Tupelo, and Loblolly Pine (Table 1). Most of the hardwoods like Bald Cypress, Water Tupelo, and oaks can be found in the riparian floodplain of the watershed including similar numerous other blackwater river flood plains along the Atlantic coast of the south-eastern USA. Trees that live in water for long periods usually have buttressed trunks, tangled, braided

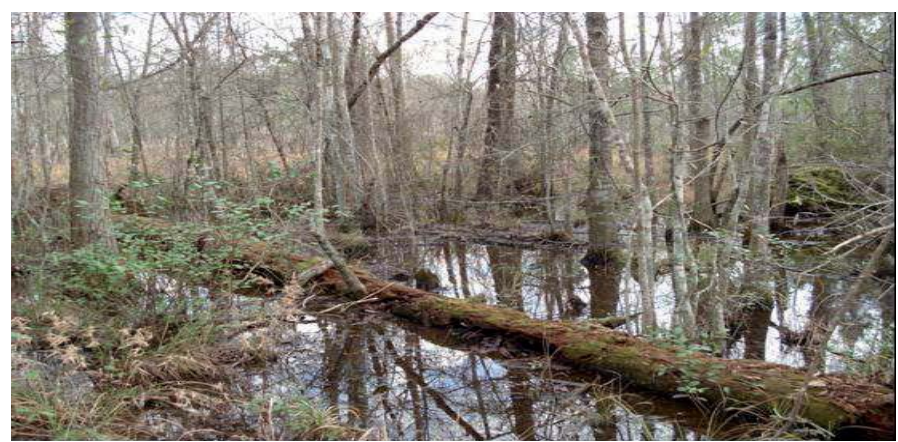

FIGURE 2. Photograph of Turkey Creek stream showing dense vegetation and woody debris on its floodplain 
TABLE 1. Tree type distribution in the Turkey Creek (TC) watershed (after Haley 2007)

\begin{tabular}{|l|c|}
\hline Tree type & $\begin{array}{c}\text { \% within } \\
\text { forest in TC } \\
\text { watershed }\end{array}$ \\
\hline Bald Cypress - Water Tupelo & 23 \\
\hline Thinned forest & 27 \\
\hline $\begin{array}{l}\text { Bottomland hardwood - Yellow } \\
\text { Pine }\end{array}$ & 2 \\
\hline Loblolly Pine & 26 \\
\hline Loblolly Pine - hardwood & 3.5 \\
\hline Loblolly Pine - Longleaf Pine & 1.5 \\
\hline Longleaf Pine & 1.3 \\
\hline Pond Pine & 0.7 \\
\hline Slash Pine - hardwood & 0.3 \\
\hline $\begin{array}{l}\text { Southern Red Oak - Yellow } \\
\text { Pine }\end{array}$ & 0.1 \\
\hline $\begin{array}{l}\text { Sweet Bay-Swamp Tupelo } \\
\text { - Red Maple }\end{array}$ & 7.6 \\
\hline Sweet Gum - oak - willow & 6.4 \\
\hline Sweet Gum - Yellow Poplar & 0.6 \\
\hline Total & 100 \\
\hline
\end{tabular}

roots, or protrusions like cypress knees to obtain oxygen when underwater.

The watershed was heavily impacted by hurricane Hugo in September 1989, and the forest overstory trees were almost completely destroyed (Hook et al. 1991). The current forests on the watershed are a mixture of remnant large trees and natural regeneration of pine and hardwood trees. The forests are managed using prescribed fire and thinning for restoration of those native forest species also for supporting habitat requirements for the endangered red cockaded wood peckers (Pinoides borealis) (La Torre Torres et al. 2011). The vegetation on the riparian floodplain of the Turkey Creek stream is a mixed forest comprising mostly of bottomland hardwood including cypress and some pine.
In the Turkey Creek watershed hydrologic monitoring consists, among others, of stream flow gauging at its main outlet on highway $41 \mathrm{~N}$ bridge, using real time stage measurements at 15-minute intervals with SatLink-2 antenna interfaced with Sutron Model 8210 datalogger connected to the pressure transducer at the bottom of the stream (Amatya and Jha 2011) - Figure 1. There are no other flow monitoring stations upstream in the main channel for validating the results calculated by the method developed herein and formulated below.

Cypress (Taxodium) is one of the types of riparian vegetation among other pine and hardwood in the Turkey Creek watershed. The cypress (Cupressus sempervirens) is a main division of the Coniferae known as the Araucariaceae. Its appearance resembles a flame-shaped, tapering, cone with pale, green, feathery leaves. It rarely exceeds $15-20 \mathrm{~m}$ in height and grows $0.3-0.45 \mathrm{~m}$ annually for the first 8 to 10 years. After the age of 40 years, cypress growth is barely perceptible (Briand 2000). Cypresses live in moist or swampy regions along the Atlantic coastal plain, such as: eastern Texas, the southern coastal plains of Louisiana, Mississippi, Alabama, Georgia, Florida, South Carolina, Arkansas, western Tennessee, south-eastern Missouri and southern Illinois, and the coastal regions of California. The cypress trees are characterized by the unique root system called knees (Fig. 3) that appear just above the water line, up to $1.2 \mathrm{~m}$ above water surface. True to their name, the knee portion of the root system appears as a swollen, enlarged area toward the base of the trunk. The knees supply oxygen to the root system that is below the water 
level and the earth. These knees vary in height from several centimeters to more than $3.7 \mathrm{~m}$, depending apparently upon the average water level of the site. Knees are less likely to form in absence of flooding or where permanently standing water is $30 \mathrm{~cm}$ or more in depth. However, small knees have been observed on many trees not subjected to flooding and it is not uncommon for ornamental trees to produce knees. Research has found no physiological function for cypress knees. They may be beneficial as aeration organs but are not of critical importance to survival. Knees may also help to anchor trees because they develop large masses of roots (Brown 1984). The extensive root system along with a buttressed base makes bald cypress wind firm in soft, wet soils. Even winds of hurricane force, characteristics to the coastal plain, rarely overturn them.

\section{RESULTS}

\section{Cypress knee flow resistance calculation}

First, in order to determine the cypress knee flow resistance, hydraulic characteristics of this vegetation on the Turkey Creek watershed were measured. The inventory sampling of the vegetation in the main channel, existing in the water flow zone, was performed at riparian stream CS-4 cross-section (Fig. 1), where cypress knees are dominant vegetation (Fig. 4).

The side lengths of the $A_{\text {pro }}$ surface were, respectively, 3.7 and $4 \mathrm{~m}$ and there were 32 stems in this area, while the size of the base and the top were respectively in the range of 4-24 and 2-6 cm. The most often occurring plants have a stem diameter of 9-14 $\mathrm{cm}$ at the base (41\%) and 3-4 $\mathrm{cm}$ at the top (53\%) - Figures 5 and 6 . Equation (8) was used to determine the cypress knees substitute diam-

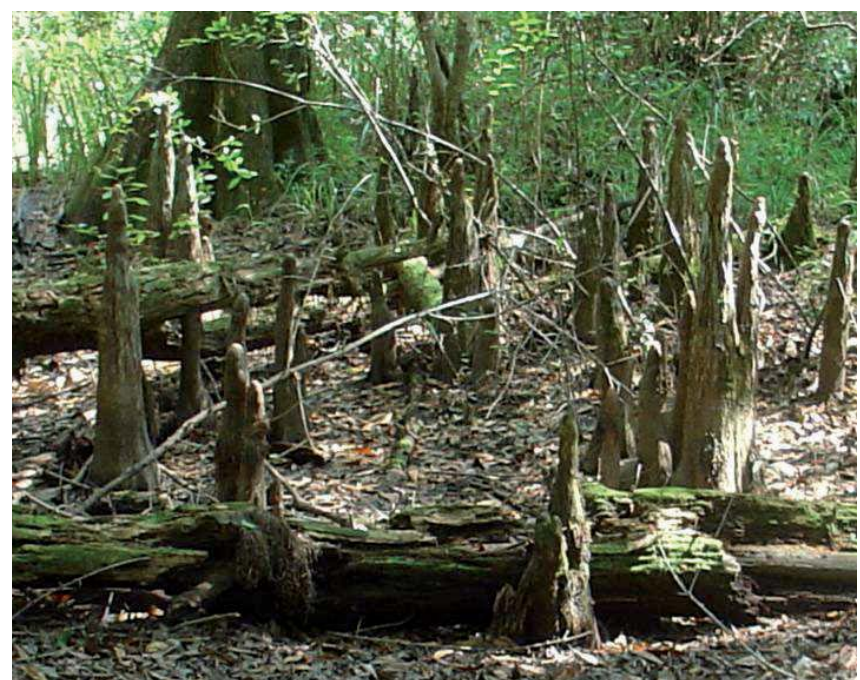

FIGURE 3. Cypress knee communities (the Turkey Creek watershed) 


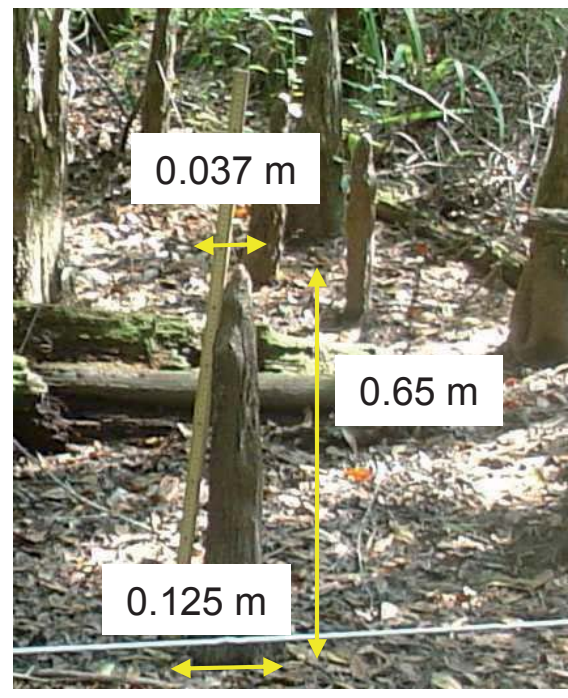

FIGURE 4. Average cypress knee geometric characteristic in main channel at CS-4 cross-section

eter. The substitute distance between the trees was calculated by means of Equation (9). The determination of $k_{s}$ values was based on measurements of bottom forms in this cross-section and totalled $0.10 \mathrm{~m}$.
It can be assumed that the shape of a cypress knee is similar to a frustum of a cone and the mean geometrical parameters of the substitute plant (diameter of the base, height, and diameter of the top) are shown in Figure 4. Height of the stems covering the $A_{\text {pro }}$ inventory area was higher than the water depth for the bank water in the CS-4 cross-section (Fig. 7). Therefore, in the Pasche method all the 32 plants were considered to be high vegetation $\left(H_{\text {plant }}>\right.$ water depth). The calculated mean hydraulic parameters for cypress knee in CS-4 cross-section have been presented in Table 2. The $d_{\text {tree }}$ substitute diameter mentioned in Table 2 has been calculated with the shape of the stem of a cypress knee being approximated to a cylinder. So as to determine the influence of the shape of a cypress knee on the flow calculation in the analyses, two cases have been taken into consideration: in Case 1 the substitute plant was approximated to a cylinder of a $0.08 \mathrm{~m}$ diameter, while in Case 2

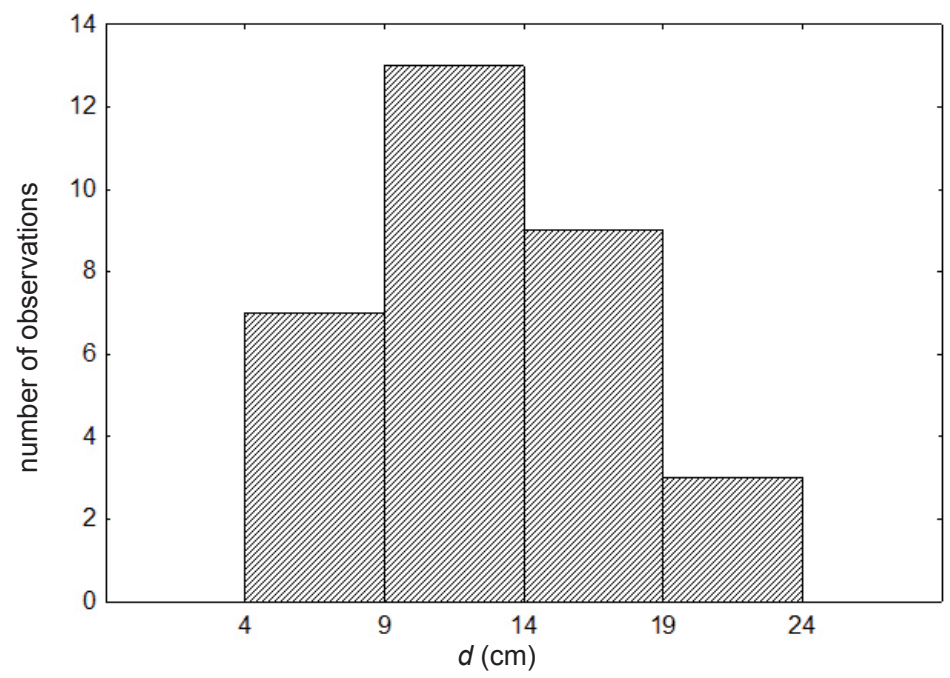

FIGURE 5. Histogram of cypress knee stem diameter (base) 


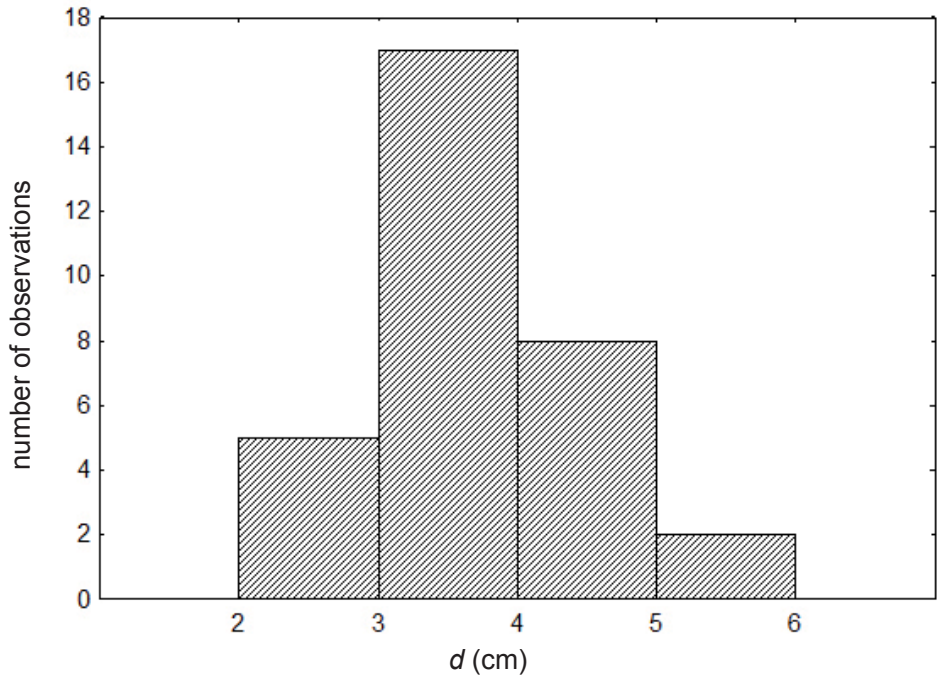

FIGURE 6. Histogram of cypress knee stem diameter (top)

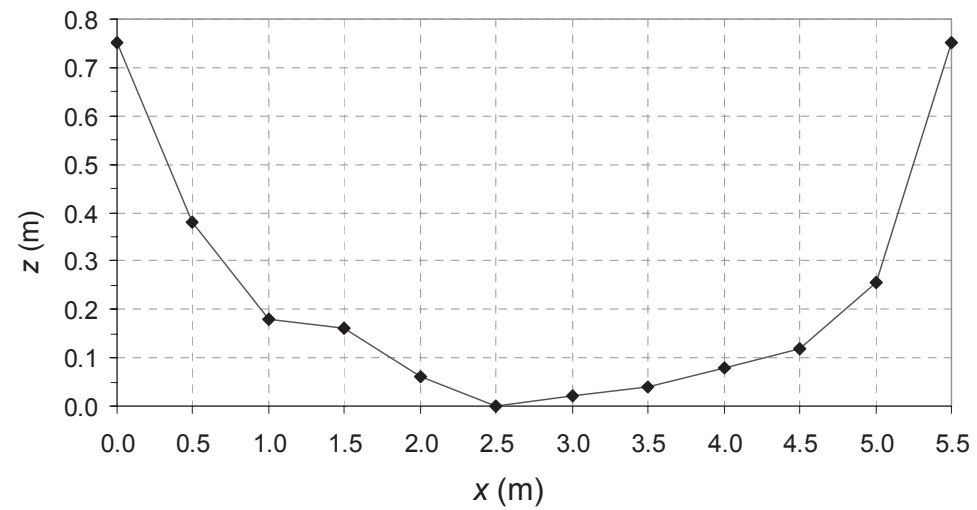

FIGURE 7. CS-4 channel cross-section

TABLE 2. Geometric cypress knee characteristic estimated for the main channel riparian at cross-section CS-4

\begin{tabular}{|c|c|c|c|c|}
\hline $\begin{array}{c}A_{\text {pro }} \\
\left(\mathrm{m}^{2}\right)\end{array}$ & $n_{\text {tree }}$ & $\begin{array}{c}d_{\text {tree }} \\
(\mathrm{m})\end{array}$ & $\begin{array}{c}a_{x} \\
(\mathrm{~m})\end{array}$ & $\begin{array}{c}a_{y} \\
(\mathrm{~m})\end{array}$ \\
\hline 14.8 & 32 & 0.08 & 0.68 & 0.68 \\
\hline
\end{tabular}

it was approximated a frustum of cone (Fig. 8). In both the cases the mean distances between the plants $\left(a_{x}\right.$ and $\left.a_{y}\right)$ are the same. In Case 2 the diameter $\left(d_{p}\right)$ of the plant at the level of water surface is a function of water depth $(H)-d_{p}=\mathrm{f}(H)$.

In Case 2 for a given depth $(H)$, the diameter of the stem at the $d_{p w}$ water level is calculated based on the substitute plant geometry, then the shape of the plant is approximated to a cylinder of the diameter $d_{p}, d_{p}=\left(d_{p w}+d_{p b}\right) / 2$ (Fig. 8). Figure 9 shows how, in both the cases, the diameter values for the substitute plant change as a function of the 
1

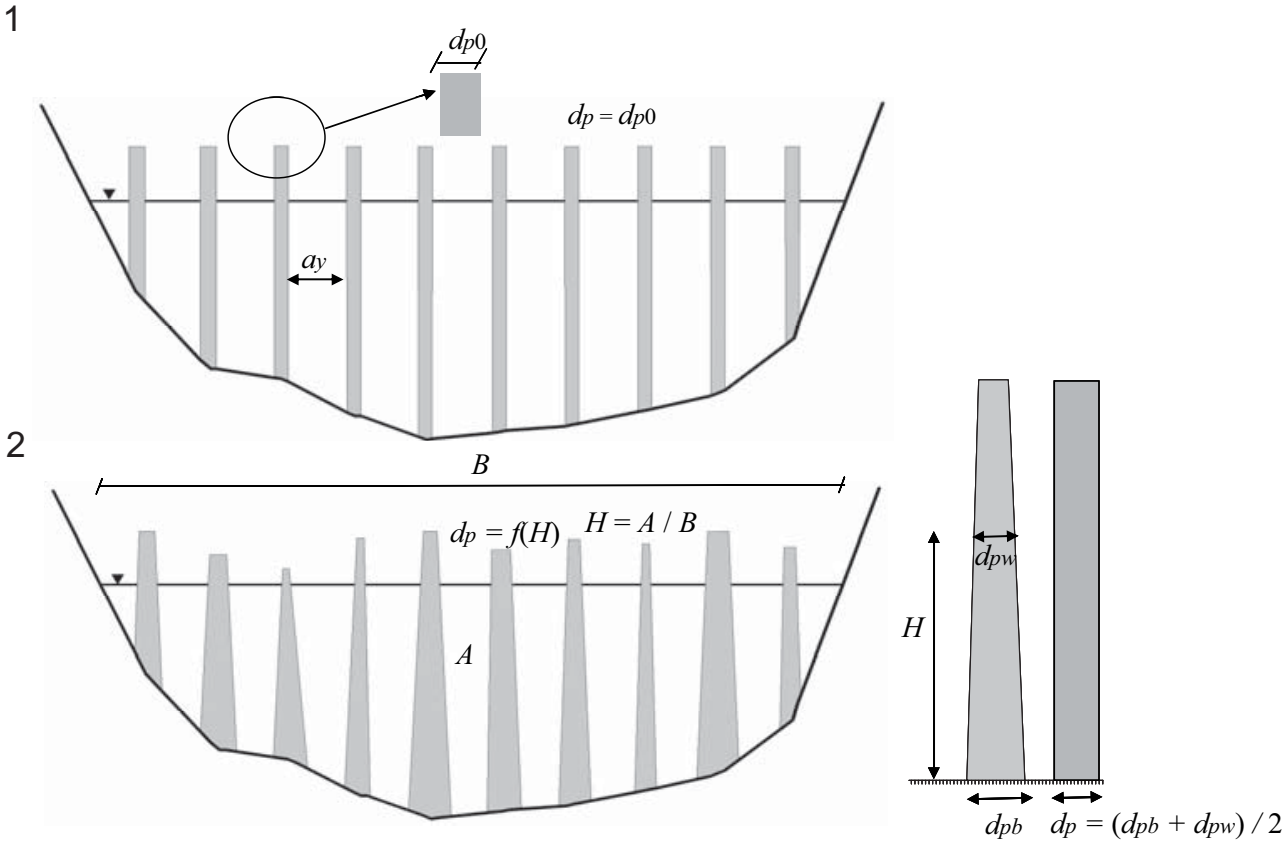

FIGURE 8 . The two analyzed shapes of a substitute stem: Case 1 - cylinder; Case $2-$ frustum of cone; $A$ - cross area of flow $\left(\mathrm{m}^{2}\right) ; B$ - width of water surface (m), $H$ - hydraulic water depth (m)

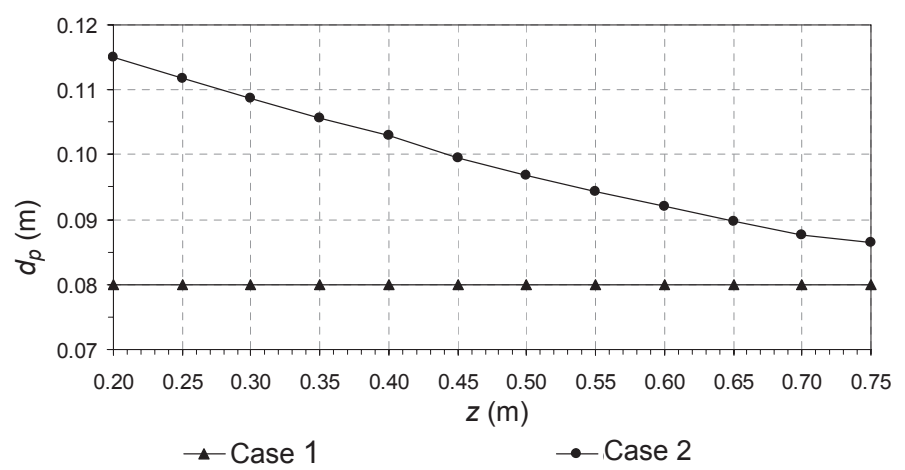

FIGURE 9. Substitute plant diameter $\left(d_{p}\right)$ as a function of the level of the water surface $(z)$

level of the water surface $(z)$ in the CS-4 surface position from 0.20 to $0.75 \mathrm{~m}$ at cross-section. In the calculations for the the CS- 4 cross-section, $h_{z}$ changes in the analyzed level of the water surface $(z)$, the respective hydraulic depth $(H)$ is calculated, which is assumed as the height of the submerged parts of the trees $\left(h_{z}\right)$ in Equation (3). For the change in water range of $0.12-0.56 \mathrm{~m}$.

In Case 2 the substitute diameter is larger than the stem diameter of Case 1 by $8-44 \%$ and the greatest differences occur for small depths. 
Equations (2), (3), (4), (5) and (6) ference occurs when the water surface elhave been used for the calculations of the $\lambda$ resistance and in the further discussions regarding Cases 1 and 2 Indices 1 and 2 have been assumed in the pictures. The calculated values of the friction factor $\left(\lambda_{p}\right)$ for cypress knee stem are presented in Figure 10 for the two analyzed cases. evation $z=0.20 \mathrm{~m}$, which corresponds to the stem submergence depth $H=0.12 \mathrm{~m}$. Figure 11 shows that a $10 \%$ change in the stem diameter entails a friction factor $\left(\lambda_{p}\right)$ change by $14 \%$.

The total resistance coefficient $(\lambda)$ is a sum [Equation (6)] of $\lambda_{p}$ - the resist-

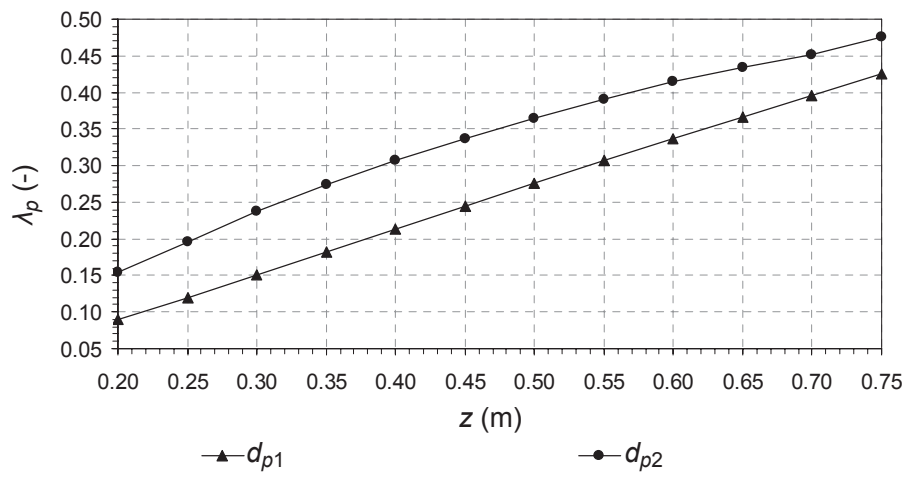

FIGURE 10. Variability of friction factors $\lambda_{p 1}$ and $\lambda_{p 2}$ as a function of the level of water surface

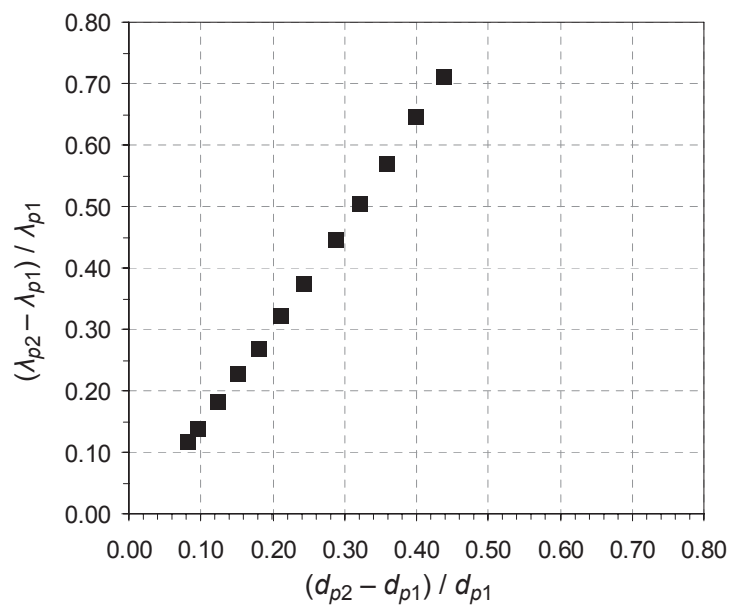

FIGURE 11 . Sensitivity of the $\lambda_{p}$ coefficient to changes in stem diameter

If the stem diameter changes related to water depth changes are taken into consideration, the plant friction coefficients, are larger by $12-71 \%$. The greatest dif- ance coefficient of high vegetation, and $\lambda_{s}-$ the resistance coefficient related to the roughness of the section surface [Equation (2)]. In both the analyzed cas- 
es the roughness height $\left(k_{s}\right)$ is the same. Therefore, the $\lambda_{s}$ values do not change, but they influence the total friction coefficient $(\lambda)$ which falls in the range of $0.25-0.49$ for a constant value of $d_{p}$ and assumes values from the range of 0.32 -0.55 (Fig. 12) for a variable stem diameter.

In Case 2 the $\lambda$ coefficient is larger by $10-32 \%$ than the values reached in the case of a constant $d_{p 1}$ diameter. In hydraulic calculations the Manning friction factor $(n)$ is one of the most frequently used flow resistance coefficients (Chow 1965, Rantz et al. 1982). Based on the
Darcy-Weisbach formula [Equation (7)] and the Manning formula the following dependence between $n$ and $\lambda$ can be determined:

$n=\sqrt{\frac{\lambda R^{1 / 3}}{8 \mathrm{~g}}}$

Figure 13 shows the $n$ coefficient values calculated based on Equation (10) for the two analyzed cases. In Case 1 with a constant stem diameter $n$ changes in the range from 0.040 to 0.071 and in the Case 2 with a variable stem diameter

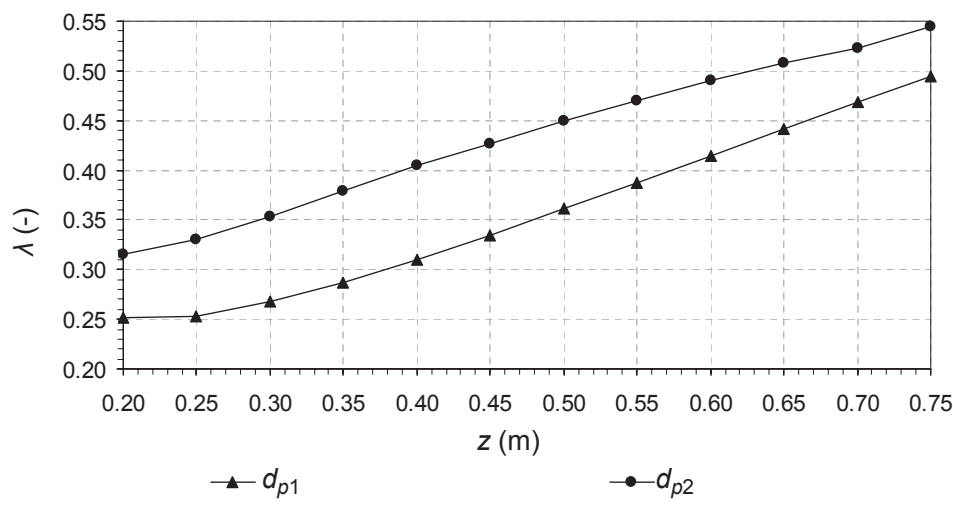

FIGURE 12. Total friction factor $(\lambda)$ as a function of water level $(z)$

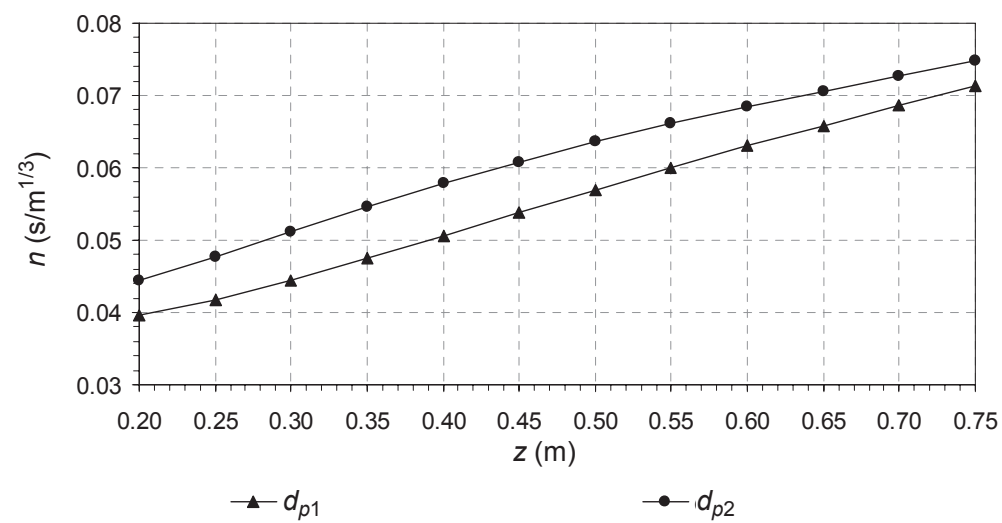

FIGURE 13. Variability of Manning $n$ for Case 1 and Case 2 
assumes values from 0.044 to 0.075 . Accordingly in Case 2, Manning $n$ is higher than the values approximated for Case 1 by $5-15 \%$. The sensitivity of Manning $n$ to stem diameter changes is presented in Figure14. The maximum growth of $n$ by approximately $15 \%$ occurs, when the stem diameter is higher by approximately $30 \%$, but further diameter growth does not entail Manning coefficient growth.

\section{Discharge capacity calculation}

The flow resistance changes due to vegetation stem diameters influence the values of water flow velocities (Fig. 15) and, thus, also influence the discharge capacity of the channel at the CS-4 cross-section.

Since the flow resistance in the case of a constant stem diameter $\left(d_{p 1}\right)$ is lower than in the case, when the diameter

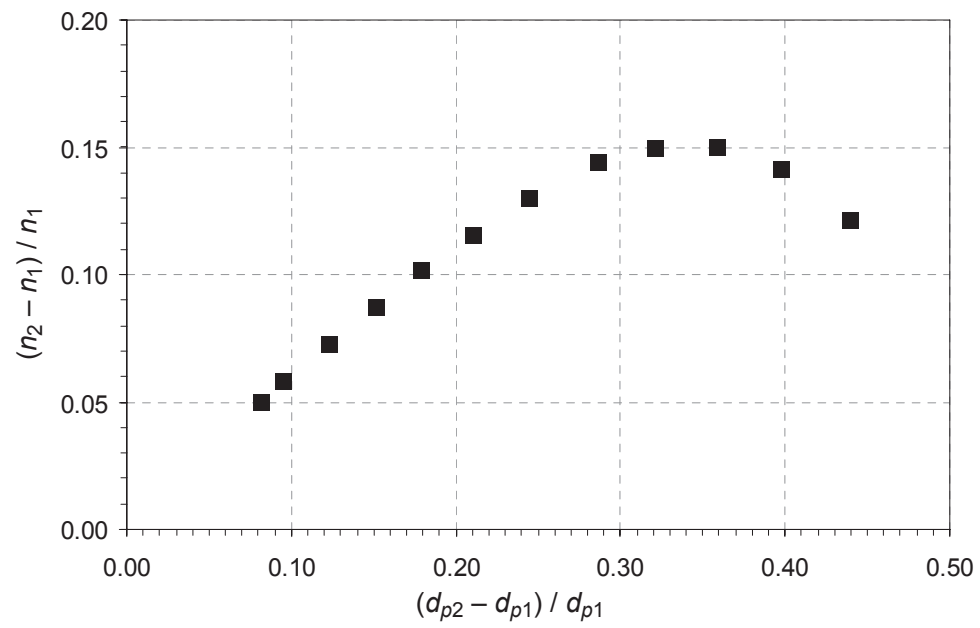

FIGURE 14. Sensitivity of Manning $n$ to variability of $d_{p}$

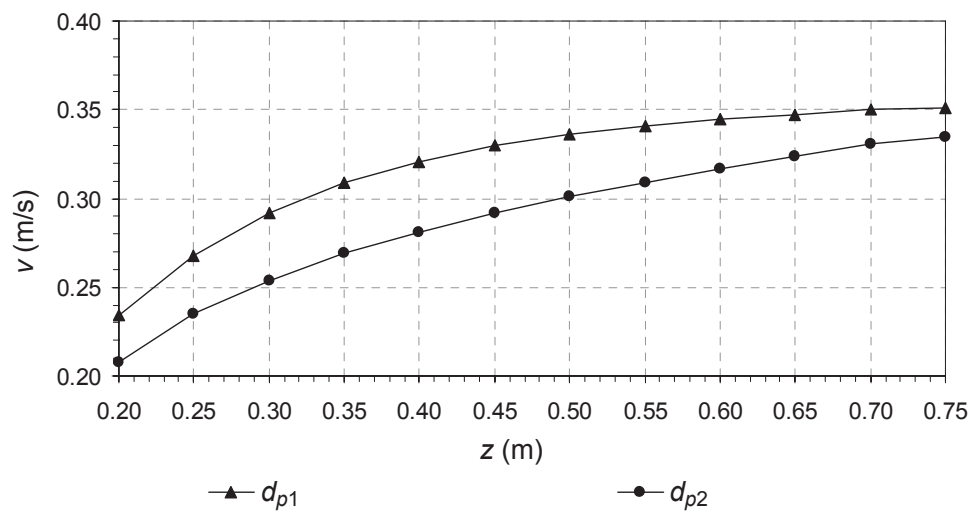

FIGURE 15. Estimated water flow velocities $(v)$ for two analyzed cases 
changes depending on the depth $\left(d_{p 2}\right)$, the relationship between the water flow velocities is inverse. In Case 1 the velocities are by $5-13 \%$ larger than in Case 2 . As a result, these differences also influence the discharge capacity (Fig. 16). ference of $0.04 \mathrm{~m}$ accounts for approximately $11 \%$ of the water depth in the channel $(H=0.37 \mathrm{~m})$ and such a depth is reached in Case 1, when the discharge is $0.6 \mathrm{~m}^{3} / \mathrm{s}$.

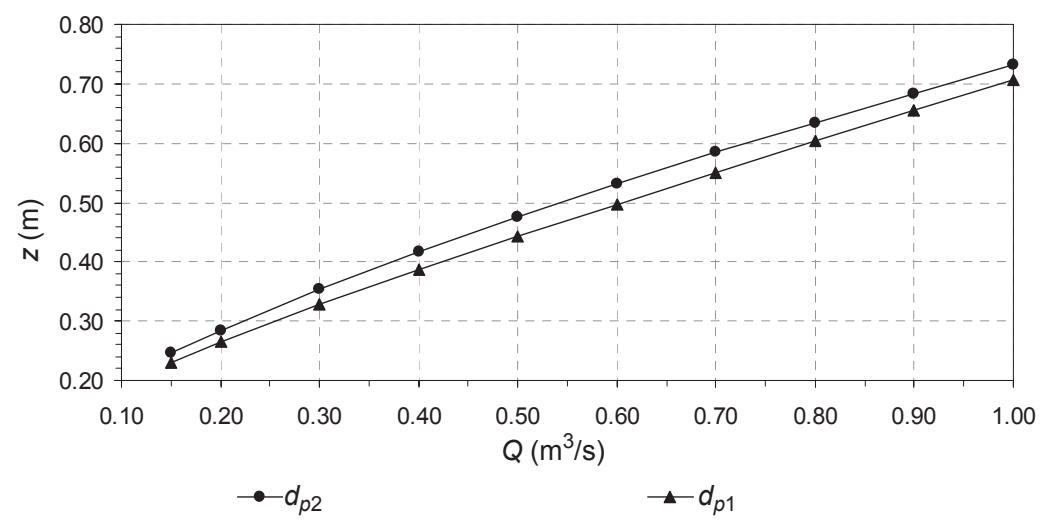

FIGURE 16. Calculated rating curve for two analyzed cases

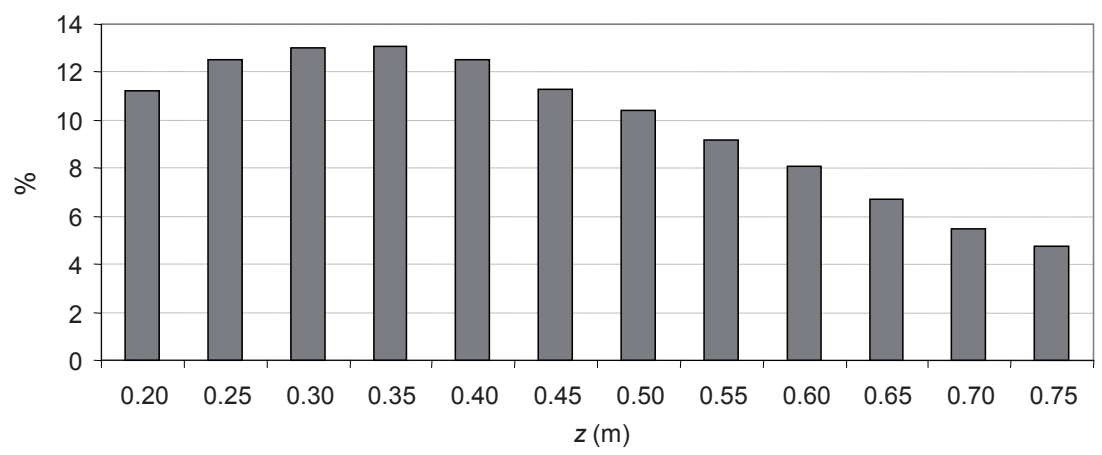

FIGURE 17. Flow reduction in Case 2

When the stem diameter changes are taken into account (with higher $n$ and lower velocity), the channel discharge capacity in the CS-4 cross-section decreases also by $5-13 \%$ (Fig. 17).

Significance of the influence of the $d_{p}$ changes on the friction factor in the calculations results at the maximum difference of water surface elevation of $0.04 \mathrm{~m}$ and for $Q=0.6 \mathrm{~m}^{3} / \mathrm{s}$ (Fig. 15). The dif-

\section{DISCUSSION}

As expected, the introduction of a variable diameter of cypress knee substitute plant in the channel influenced the values of the flow resistance. The friction coefficients $\lambda_{p}$ calculated based on the methodology of variable stem diameter assumed in this study were found to be 
$12-71 \%$ larger (Fig. 17) than the resistance coefficients estimated for a constant stem diameter of the cypress knee, at the CS-4 cross-section of the Turkey Creek watershed. These differences are larger than the differences in the dp values which changed in the range from 8 to $44 \%$ (Fig. 18). The change in $\lambda_{p}$ values in Case 2 are related to the arrangement of Equation (3), in which $\lambda_{p}$ is linearly dependent on dp, but also on the values of the drag coefficient $\left(C_{W R}\right)$ as described by Equation (4) - Figure 19. Drag coefficient is a non-linear function of the stem width. The largest percentage difference in the values of $d p$ and $\lambda_{p}$ compared to their values in Case 1 occur for small depths $(z=0.20 \mathrm{~m}$, which corresponds to $H=0.12 \mathrm{~m})$. These differences decrease as the depth increases, which is related to the ever decreasing changes in the substitute plant stem diameter. At the depth $H=0.56 \mathrm{~m}(z=0.75 \mathrm{~m})$ the substitute plant stem diameter in Case 2 is $0.087 \mathrm{~m}$, while in Case 1 it is $0.081 \mathrm{~m}$.

Despite the largest percent differences in the values of $d_{p}$ and $\lambda_{p}$ occurring in small depths, the largest value difference of the friction coefficient $\left(\lambda_{p}\right)$ is 0.095 and takes place for the depth

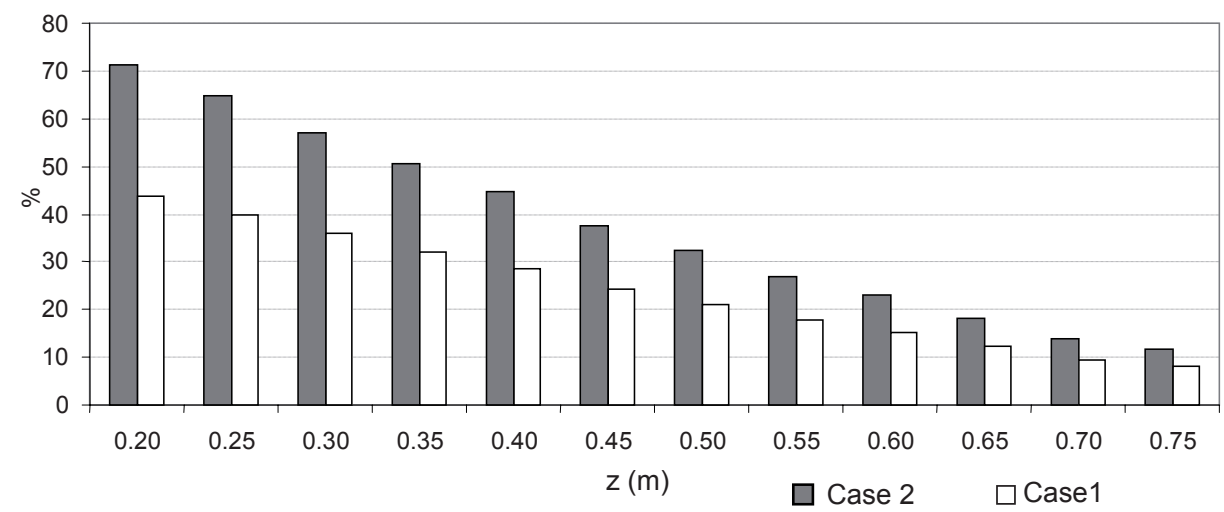

FIGURE 18. Growth values of $\lambda_{p}$ and $d_{p}$ in Case 2 compared to Case 1

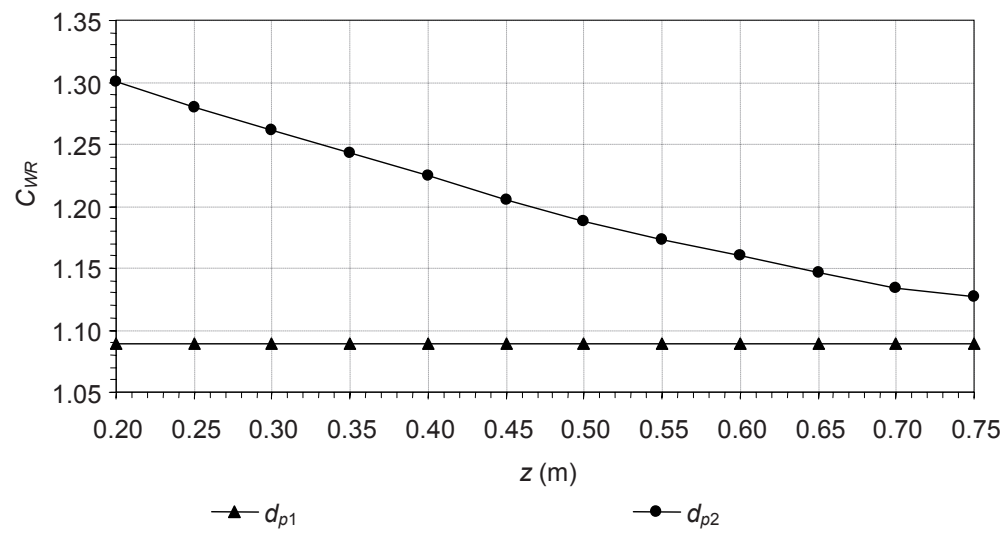

FIGURA 19. Function of drag coefficient $\left(C_{W R}\right)$ and water level $(z)$ for Case $1\left(d_{p 1}\right)$ and Case $2\left(d_{p 2}\right)$ 
$\mathrm{H}=0.28 \mathrm{~m}(z=0.40 \mathrm{~m})$ - Figure 20. When the depth is $0.28 \mathrm{~m}(z=0.40 \mathrm{~m})$ and below the differences between $\left(\lambda_{p 2}\right)$ and $\left(\lambda_{p 1}\right)$ increase and then, as the depth increases, they decrease. They reach their highest values $(>0.08)$ when $\mathrm{H}$ is in the range of $0.20-0.41 \mathrm{~m}(z=0.30-0.55 \mathrm{~m})$ - Figure 20. of changes in $d_{p}$ changes may enhance the model calibration.

The Manning coefficient values estimated with the assumed method using Equation (13) are congruent with the values presented in the tables given by Chow (1959). The values estimated by Chow for small natural water streams

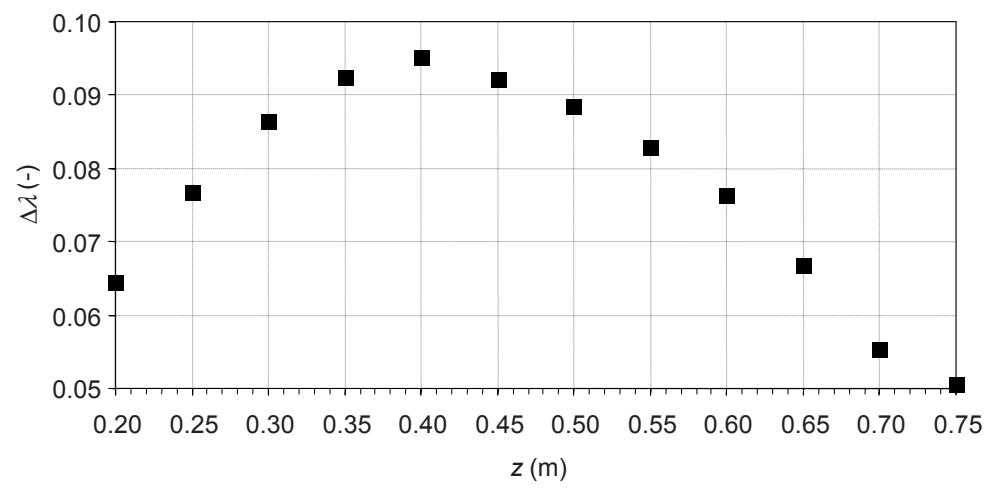

FIGURE 20. Growth values of friction factor $(\lambda)$ in Case 2 compared to Case 1

Since the largest difference of flow resistance values occurs when the water surface elevation $z=0.40 \mathrm{~m}$, it is for this water level that the largest differences in water velocity occur (Fig. 15). The percent reduction of water flow is also at its largest $(13 \%)$ when $z$ is in the range of $0.3-0.4 \mathrm{~m}$ (Fig. 17). If the influence of the $d_{p}$ changes on the friction factor is taken into consideration, the water surface elevation in Case 2 is higher than the water level in Case 1 at the same water flow. The maximum difference of approximately $0.04 \mathrm{~m}$ corresponds to roughly $11 \%$ of the water depth in the channel $(H=0.37 \mathrm{~m})$ and this water depth is reached in Case 1 at the flow of $0.6 \mathrm{~m}^{3} / \mathrm{s}$. Such differences may be significant in the case of calibration of a hydrodynamic model where consideration with vegetation fall in the range between 0.05 and $0.08 \mathrm{~m}^{-1 / 3} \cdot \mathrm{s}$, and the mean $n$ value is 0.07 . The Manning $n$ values estimated in this study are slightly lower and range between 0.044 and $0.075 \mathrm{~m}^{-1 / 3} \cdot \mathrm{s}$. The mean Manning coefficient value is also lower - it is $0.061 \mathrm{~m}^{-1 / 3} \cdot \mathrm{s}$. The mean $n$ coefficient value presented in the tables for this type of stream is approximately $15 \%$ higher than the value estimated based on the methodology assumed in this study, where a variable mean stem diameter, dependent on the water depth, has been taken into consideration. A considerably larger difference of $27 \%$ occurs for Case 1, where the stem diameter is assumed to be constant. The differences result from actually occurring stem geometry and spatial structure (distances between plants) which have been ap- 
proximated during the calculations. The mean Manning coefficient in Case 2 is approximately $11 \%$ larger than the $n$ coefficient estimated in Case 1. The values presented in the tables need to be treated as an approximation of the flow resistance, but the Manning $n$ values estimated in this study for a channel occupied by stems of cypress knee can be used in hydraulic calculations. Of course, in order to confirm the accuracy of the estimated flow resistance coefficients, hydrometric measurements need to be taken in the CS-4 cross-section in the future. It needs to be emphasized that since cypress knee stems are present in the channel and they distort the flow field, such a measurement is quite complicated.

The estimated Manning coefficient values herein are significantly lower than the values assumed in the SWAT hydrological model created by Amatya and Jha (2011), where the $n$ coefficient in the river channel was validated with measurement only at the main watershed outlet (Fig. 1). The coefficient assumed in the SWAT model, which is $n=0.1 \mathrm{~m}^{-1 / 3} \cdot \mathrm{s}$, does not correspond to the actual flow resistance which occurs in reality. Its high value was possibly compensated by other uncertain elements present in the model (e.g. numerical terrain model, land use, stream channel geometry and roughness parameters). However, the $n$ value of 0.045 estimated by USGS (Arcement et al. 1990) at the approach channel just upstream of the gauging station of this watershed in the Type II contracted opening (at the bridge) method of discharge computation (Rantz et al. 1982) for adjusting the high discharge obtained by the existing rating curve is at the lower end of the range $(0.044-0.075)$ obtained by the method described here.

\section{CONCLUSIONS}

The results of this study, based on the assumed methodology of estimating flow resistance developed by Pasche and on the cypress knee geometric characteristics field measurements, lead to the following conclusions:

- If the variability of vegetation stem diameter is taken into consideration in the calculations, an increase by $10-32 \%$ in the values of friction coefficients $\lambda$ occurs.

- When the shape of the cypress knee stem is substituted with a cylindrical plant with a constant stem diameter $\left(d_{p}=0.08 \mathrm{~m}\right)$, the calculated high vegetation friction factor $\left(\lambda_{p}\right)$ falls in the range of 0.09-0.425 (Case 1).

- When the diameter of the stem $\left(d_{p}\right)$ at the water stage is assumed to change together with the depth, $d_{p} \in[0.121-$ $-0.087 \mathrm{~m}]$, the friction factor of the substitute plant with a shape of a frustum of a cone, assumes values from the range of $0.154-0.475$ (Case 2).

- The values of $\lambda_{p 2}$ in Case 2 are 12 $-71 \%$ larger than the values of $\lambda_{p 1}$ obtained in Case 1. As the water depth in the channel increases, the substitute plant stem diameter values remain similar in both the analyzed cases, which causes the difference between the friction factor values to decrease.

- The greatest differences between the $\lambda_{p}$ values calculated for the analyzed cases occur for the water depth $(H)$ range of $0.20-0.41 \mathrm{~m}$. 
- The total friction factor $(\lambda)$ taking into consideration the bed resistance, assumes values in the range of $0.251-$ -0.495 in Case 1 and $0.316-0.545$ in Case 2.

- When the depth-dependent variability of the stem diameter is taken into account in the calculation, the water velocity and discharge are reduced by $5-13 \%$. The greatest changes in the flow reduction and the velocity occur for those depths, where there are the greatest differences in the flow resistance between the two analyzed cases.

- Because of the influence of the $d_{p}$ changes on the friction factor, the maximum difference in the water surface level is $0.04 \mathrm{~m}\left(Q=0.6 \mathrm{~m}^{3} / \mathrm{s}\right)$. The difference of $0.04 \mathrm{~m}$ accounts for roughly $11 \%$ of the water depth in the channel $(H=0.37 \mathrm{~m})$ and such a water depth is reached in Case 1, when the discharge is $0.6 \mathrm{~m}^{3} / \mathrm{s}$.

- The Manning coefficients $n$ estimated based on friction factors $\lambda$ changed between 0.040 and $0.071 \mathrm{~m}^{-1 / 3} \cdot \mathrm{s}$ in Case 1 and between 0.044 and $0.075 \mathrm{~m}^{-1 / 3} \cdot \mathrm{s}$ in Case 2. Because of the cypress knee stem friction factor growth, the Manning friction coefficients increase as the depth increases. The mean $n$ value in Case 2 is approximately $11 \%$ higher than in Case 1 . The estimated Manning $n$ values are lower by 15 and $27 \%$ respectively for Case 1 and Case 2, than the Chow tables values for small natural streams occupied by vegetation.

In the future, the results presented in this study should be validated by hydrometric measurements of water veloc- ity taken in the Turkey Creek watershed cross-section examined in this study. The results of this work and the analysis of these results indicate that the inclusion of the variability of cypress knee stem diameter in the calculations may be relevant not only in the process of calibration of friction coefficients in a hydrodynamic model of water flow in the Turkey Creek, but also in back calculation of high flood discharges outside of the rating curve range as currently done by the USGS for the Turkey Creek watershed. The currently available high resolution LiDAR data for the Turkey Creek watershed (Amatya et al. 2013) may also be used to estimate the type and height of riparian vegetation for estimating $n$ values needed in hydrologic and hydrodynamic models.

\section{Acknowledgements}

The authors would like to thank Julie Arnold, Forestry Technician, and Andy Harrison, Hydrologic Technician, both at US Forest Service in Cordesville (SC), and Andrea Hughes at US Army Corps of Engineers (SC) for help in the field works, and Jose Martin, former student at Gainesville State College (GA), for help with GIS works of the watershed, stream channel, and its cross-sections.

\section{REFERENCES}

AMATYA D.M., TRETTIN C., PANDA S., SSEGANE H. 2013. Application of LiDAR data for Hydrologic Assessments of Low-gradient Coastal Watershed Drainage Characteristics. J. Geograp. Inf. System 5, 171-195. doi:10.4236/ jgis.2013.52017. 
AMATYA D.M., JHA M.K. 2011. Evaluating the SWAT model for a low-gradient forested watershed in coastal South Carolina. Trans. ASABE 54 (6), 2151-2163.

ARCEMENT Jr. G.J. SCHNEIDEr V.R. 1990: Guide for Selecting Manning's Roughness Coefficients for Natural Channels and Flood Plains. U.S. Geological Survey Water-Supply Paper 2339, Washington, D.C. Retrieved from http:// www.fhwa.dot.gov/bridge/wsp2339.pdf.

BENJANKAR R., EGGER G., JORDE K. 2009: Development of a Dynamic Floodplain Vegetation Model for the Kootenai River, USA: Concept and Methodology. 7th International Symposium on Ecohydraulics, 12-16 January 2009 Concepcion (Chile).

BONNESS M.S. 2011: Cypress Knees Exploit Stumps Palmetto. Quart. J. Florida Native Plant Soc. 28 (2), 5-12.

BRIAND C.H. 2000: Cypress Knees: An Enduring Enigma. Arnoldia 60 (4),19-25.

BROWN C.A. 1984: Morphology and biology of cypress trees. In: Cypress Swamps, Ewel K.C. Odum H.T. (Eds), 16-24. University of Florida Press, Gainesvile.

CHOW VT. 1959: Open Channel Flow. McGraw-Hill Book, Singapore.

DVWK - MERKBLÄTTER 220, 1991. Hydraulische Berechnung von Fließgewässern, DK 551.51/54 Fließgewässer, DK 532.543 Hydraulik, DVWK - Merkblätter 220/1991. Kommissionsvertrieb Verlag Paul Parey, Hamburg und Berlin.

HALEY E.B. 2007: Field measurements and hydrologic modeling of the Turkey Creek watershed, South Carolina. MS thesis. College of Charleston Charleston, S.C. [typescript].

HELMIO T. 2002: Unsteady 1D flow model of compound channel with vegetated floodplains. J. Hydrol. 269 (1-2), 89-99.

HOOK D.D., BUFORD M.A., WILLIAMS T.M.,1991: Impact of Hurricane Hugo on the South Carolina Coastal Pine Forest. $J$. Coastal Research SI (8), 291-300.

La TORRE TORRES I., AMATYA D.M., CALLAHAN T.J., SUN G. 2011: Sea- sonal rainfall-runoff relationships in a lowland forested watershed in the southeastern U.S.A. Hydrol. Proc. 25 (13), 2032-2045.

MERRITT D.M., SCOTT M.L., POFF N.L., AUBLE G.T., LYTLE D.A. 2009: Theory, methods and tools for determining environmental flows for riparian vegetation: riparian vegetation-flow response guilds. Freshwater Biology 1-20. doi 10.1111/j.1365-2427.2009.02206.x.

MIROSLAW-SWIATEK D. 2012: Unsteady 1D Flow Model of Natural Rivers with Vegetated Floodplain - An Application to Analysis of Influence of Land Use on Flood Wave Propagation in the Lower Biebrza Basin. In: Water Resources Management and Modeling, Purna Nayak (Ed.), 145-168. doi 10.5772/34845.

MIROSLAW-SWIATEK D., AMATYAD.M. 2011: Determination of plant characteristics used in discharge capacity assessment of Turkey Creek watershed on South Carolina coastal plain, USA. Ann. Warsaw Univ. of Life Sci. - SGGW, Land Reclam. 43 (2), 121-134.

NEPF H.M. 1999: Drag, turbulence, and diffusion in flow through emergent vegetation. Water Res. Res. 35, 479-489.

PASCHE E., ROUVE G. 1985: Overbank flow with vegetatively Roughened flood plains. J. Hydraul. Eng. 111 (9), 1262-1278.

RANTZ S.E. 1982: Measurement and Computation of Streamflow: Vol. 1. Measurement of Stage and Discharge. U.S. geological Survey Water Supply Paper 2175. U.S. Government Printing Office, Washington, D.C.

ROOD S.B., SAMUELSON G.M., BRAATNE J.H., GOURLEY C.R., HUGHES F.M.R, MAHONEY J.M. 2005: Managing river flows to restore floodplain forests. Frontiers Ecol. Environ. 3, 193-201.

SANTHI C., KANNAN N., ARNOLD J.G., DI LUZIO M. 2008: Spatial calibration and temporal validation of flow for regional-scale hydrologic modeling. J. American Water Resour. Assoc. 44 (4), 829-846. 
SHERIDAN J.M., LOWRANCE R., BOSCH D.D. 1999: Management Effects on Runoff and Sediment Transport in Riparian Forest Buffers. Trans. ASABE 42 (1), 55-64.

TOCKNER K., STANFORD J.A. 2002: Riverine flood plains: present state and future trends. Environ. Conserv. 29, 308-330.

WHITE M.D., GREER K.A. 2006: The effects of watershed urbanization on the stream hydrology and riparian vegetation of Los Penasquitos Creek, California. Landscape Urban Plan. 74 (2), 125-138.

WHITED D.C., LORANG M.S., HARNER M.J., HAUER F.R., KIMBALL J.S., STANFORD J.A., 2007: Climate, Hydrologic Disturbance, and Succession: Drivers of Floodplain Pattern. Ecology 88 (4), 940-953.

WILSON C.A.M.E., HORRITT M.S., 2002: Measuring the flow resistance of submerged grass. Hydrol. Process. 16, 2589-2598.

WU F. 2008: Characteristics of flow resistance in open channels with non-submerged rigid vegetation. J. Hydrodynam. 2092, 239-245.

Streszczenie: Wplyw korzeni drzew cyprysowych na opory przepływu i przepustowość doliny rzeki Turkey Creek. W artykule przeanalizowano wpływ przyjętego opisu kształtu roślinności na obliczenia hydraulicznego oddziaływania roślin. Wykorzystano metodę obliczeniową Paschego, wykorzystując wzór Darcy'ego-Weisbacha oraz modyfikację równania oporów Colebrooka-White'a. W metodzie tej istotne znaczenie ma prawidłowe oszacowanie współczynnika oporów liniowych dla roślin. Przyjęte jest założenie, że opory przepływu przy opływie naturalnie zróżnicowanej roślinności są takie same, jak przy opływie równomiernie rozmieszczonej roślinności o zastępczych parametrach, określonych na podstawie inwentaryzacji. Współczynniki oporów roślinności wysokiej (krzewy i drzewa) są w głównej mierze uzależnione od oporów opły- wanej bryły roślin i są obliczane na podstawie zastępczej przeciętnej średnicy roślin $\left(d_{p}\right)$ oraz uśrednionych odległościach między nimi w kierunku przepływu $\left(a_{x}\right)$ i poprzecznym do niego $\left(a_{y}\right)$. W artykule wyznaczono charakterystyki geometryczne związane z oporami przepływu systemu korzeni drzew cyprysowych (ang. cypress knees) występujących w korycie rzeki oraz na obszarach zalewowych rzeki Turkey, której zlewnia o powierzchni $78 \mathrm{~km}^{2}$ położona jest w Południowej Karolinie (USA). U drzew cyprysowych pionowe korzenie są ułożone w gęstej strukturze wyrastają powyżej linii zwierciadła wody. Charakterystyki geometryczne pni korzeni zostały wyznaczone w wyniku inwentaryzacji roślinności w wybranym przekroju rzeki. Obliczenia wykonano dla dwóch wariantów opisu kształtu pnia rośliny. W pierwszym wariancie przyjęto kształt cylindra o stałej średnicy, a w drugim założono, że korzenie mają kształt stożka ściętego, którego średnica zastępcza zmienia się wraz z głębokością przepływu. Dzięki przeprowadzonym obliczeniom wykazano, że dla stałej średnicy zastępczej $\left(d_{p}=0,08 \mathrm{~m}\right)$ współczynnik oporów liniowych zmienia się w zależności od głębokości przepływu w zakresie 0,09-0,425. W wariancie uwzględniającym zmienną średnicę korzenia, $d_{p} \in[0,121-0,087 \mathrm{~m}]$, współczynnik oporu rośliny przyjmował wartości z przedziału $0,154-0,475$.

MS received July 2017

\section{Authors' address:}

Dorota Miroslaw-Swiatek

Katedra Inżynierii Wodnej

Wydział Budownictwa i Inżynierii Środowiska

SGGW

ul. Nowoursynowska 166, 02-787 Warszawa

Poland

e-mail:dorotams@levis.sggw.pl

Devendra M. Amatya

Center for Forested Wetlands Research

US Forest Service

Cordesville, SC 29434

USA 